\title{
CROP WATER STRESS INDEX FOR BEANS OBTAINED FROM TEMPERATURE DIFFERENCE BETWEEN CANOPY AND AIR
}

P.E.P. ALBUQUERQUE and R.L. GOMIDE

EMBRAPA, Sete Lagoas - MG, Brazil

A.E. KLAR

Dept. Rural Engineering, State University of S. Paulo, Botucatu, Brazil

\begin{abstract}
Canopy temperature ( $\mathrm{Tc}$ ), besides serving as a parameter to estimate crop evapotranspiration $\left(\mathrm{ET}_{\mathrm{c}}\right)$, can also be used to define water stress indexes that have the advantage to serve as a reference for the rational scheduling for irrigation for a crop. One of these indexes, which has been well disseminated, is the crop water stress index (CWSI), based on the ratio between crop resistance and aerodynamic resistance $\left(r_{\mathrm{c}} / \mathrm{r}_{\mathrm{a}}\right)$, whose value can be estimated by the difference between the cropy canopy and the air $(\mathrm{Tc}-\mathrm{Ta}$ ). A study was carried out with the objective of obtaining CWSI values for beans (Phaseolus vulgaris L.), under field conditions, in which the crop was under different irrigation scheduling: $2,4,8,12$ and 16 day intervals. The experiment was conducted at Sete Lagoas, Minas Gerais State, Brazil, in the period from July through October, 1995. Tc values were measured by means of infrared thermometry at two times of the day: between 10:00 and 11:00 a.m., and between 01:00 and 02:00 p.m. The obtained results pointed to a limit of 0.15 as a reference for the beginning of water stress to occur, which is consistent with other work and other index obtained under similar conditions.
\end{abstract}

Keywords: Crop water stress index, evapotranspiration, irrigation scheduling.

\section{Introduction}

Irrigation science advances will necessarily imply in the gradual acquisition and utilization of knowledge which will conduct toward an accurate and precise control about the quality and quantity of applied water. This control has the purpose of optimizing the irrigation and other crop production practices. 
A way of rationalizing the use of irrigation water is to define the irrigation scheduling by utilizing the crop water stress index (CWSI) which has its bases on actual or real crop evapotranspiration $\left(\mathrm{ET}_{\mathrm{C}}\right)$. The CWSI may serve as a parameter to schedule irrigation and to reduce the amount of applied water and improve the crop water use efficiency, within well established levels, without compromising desirable commercial and economical yield. The CWSI can be defined as

$$
\mathrm{CWSI}=1-\frac{\mathrm{ET}_{\mathrm{C}}}{\mathrm{ET}_{\mathrm{m}}}
$$

where $\mathrm{ET}_{\mathrm{m}}$ is the maximum or potential crop evapotranspiration. Both, $\mathrm{ET}_{\mathrm{c}}$ and $\mathrm{ET}_{\mathrm{m}}$ are expressed in $\mathrm{mm} / \mathrm{h}, \mathrm{mm} /$ day or $\mathrm{mm} /$ period. They can be express also as the latent heat flux per unit area $\left(\lambda \mathrm{E}_{\mathrm{p}}\right.$ in $\left.\mathrm{W} / \mathrm{m}^{2}\right)$. The CWSI is an adimensional index. $\mathrm{ET}_{\mathrm{m}}$ can be defined as the maximum water flow rate which is directly evaporated from the soil and plants (foliage intercepted water) and evaporated from the leaves stomatas (transpiration), with the plants presenting no water or health limitation. On the other hand, water can be a limited parameter in the $\mathrm{ET}_{\mathrm{c}}$ situation. Thus, the CWSI values will change from 0 to 1: The CWSI will be 0 when $\mathrm{ET}_{\mathrm{c}}$ reaches $\mathrm{ET}_{\mathrm{m}}$ (no water stress).

The canopy temperature $(\mathrm{Tc})$ is used today as a parameter to predict $\mathrm{ET}_{\mathrm{c}}$ as well as to define CWSI ([1], [2], [3]; [4], [5]). The relationship between plant water status and Tc parameters are quite complex. Several other variables, which are not constant during the plant growth period, should be taken into account in the relation between Tc and $\mathrm{ET}_{\mathrm{c}}$. However, Tc has been easily measured and used as a key parameter for a great number of stress indexes. According to Clawson et al. [3], Idso et al. [7] were the first to use the temperature difference between the crop canopy and the air (Tc - Ta) as a way of establishing a crop water stress index.

The $T c$ values can be obtained from remote sensing equipments which are able to detect the surface temperature by means of infrared radiation. These instruments are known as infrared thermometer (IRT). Inoue [6] pointed out advantages of IRT and also verified IRT performance to detect $(\mathrm{Tc}-\mathrm{Ta})$ and plant physiology depression in parameters such as photosynthesis rate, transpiration and stomata conductance in corn and wheat.

One of their first parameters utilized as a way to establish the crop water stress index was the well known stress degree day (SDD) which presented good results in arid regions. Later, the SDD was normalized for humid regions conditions [3].

Idso et al. [7] also presented an empirical method for dealing with the CWSI problem. However, the theoretical basis of the CWSI was studied by Jackson [1] who used Tc measurements obtained from IRT to predict $\mathrm{ET}_{\mathrm{C}}$, from a vegetated surface energy balance equations.

Several authors ([2], [4], [5], [8], [9], [10]) studied the CWSI developed by Jackson [1]. Grimes et al. [9], Silva [10] and Kobayashi [5] obtained CWSI values of about $0.15,0.3$ and 0.20 for alfalfa, cotton and beans, respectively, as limits above which crop water stress will begin. These limits could be used as reference for irrigation scheduling. Pitts et al. [4] and Folegatti [2] pointed out the occurrence of clouds as an important limitation for the use of the CWSI. 
The objective of the present work was to obtain CWSI values for beans (Phaseolus vulgaris $\mathrm{L}$.) submitted to five different irrigation frequency intervals $(2,4,8,12$, and 16 days) under field condition, utilizing the IRT technique approach (Jackson [1]).

\section{Material and methods}

The field experiment was conducted at EMBRAPA, in Sete Lagoas, Minas Gerais State, Brazil, during the months of July through October of 1995.

The crop was planted in $26 / 07 / 95$ with a crop density equivalent to a stand of about 220,000 plant per hectare. Completely randomized plots were used as statistical design, with 5 treatments and 4 replications. The treatments were formed with different irrigation intervals $(2,4,8,12$, and 16 days) which started being applied 29 days after crop seedling (DAS), when the plants presented the third leaf emission.

The water volume to be added in each plot during irrigation was obtained by means of the soil water content determination (tensiometer and gravimetric) in the day of irrigation, in such a way as to bring the soil water level up to the "field capacity". The soil water holding capacity curve was used to carry out this computation.

Samples of the plants ( 3 for each plot) were collected weekly for determination of plant height (hc) and leaf area index (LAI). Whenever clear sky conditions occurred, at selected crop growth stages, readings of abaxial stomata resistance $\left(r_{\mathrm{S}}\right)$ were obtained from some well developed and lightened leaves (from 4 plants in each plot) between 10:00 and 12:00 hours, with a diffusion porometer. In the last sample, crop yield and yield components were evaluated.

A portable electronic weather station, installed $2 \mathrm{~m}$ above soil surface, provided the following local daily climatic data: average, maximum and minimum air temperature, rainfall, and global solar radiation $\left(R_{S}\right)$. Also, a totalizing anemometer was installed 2 $\mathrm{m}$ above soil surface, close to the field trial. Continuous data registration were obtained from an analogical electronic diagram of net radiation $\left(R_{n}\right)$, soil heat flux $(G)$, and albedo $(\propto)$. In order to carried out the $\mathrm{R}_{\mathrm{n}}$ and $\propto$ measurements, a net radiometer and albedometer sensors were installed $1.5 \mathrm{~m}$ above soil surface in the treatment irrigated each 2 days (T2). Soil heat flux plates sensors were placed $2 \mathrm{~cm}$ below soil surface in the treatments irrigated each 2,8 , and 16 days (T2, T8, and T16 respectively) to obtain $\mathrm{G}$ readings. Other climatic parameters, such as Class A pan water evaporation, sunshine hours, atmospheric pressure, and air relative humidity were obtained from EMBRAPA's main standard Climatological Weather Station, located about $1500 \mathrm{~m}$ away of the field trial.

The canopy temperature (Tc) was taken daily, within two periods: from 10:00 to 11:00 hours and from 13:00 to 14:00 hours, always with under clear sky conditions. The following IRT was used: $1{ }^{\circ} \mathrm{C}$ field of view, temperature range -30 to $300^{\circ} \mathrm{C}$, precision of $\pm 1.5^{\circ} \mathrm{C}$, sensibility of $0.1^{\circ} \mathrm{C}$, response time of about $1 \mathrm{~s}$, spectral band of 8 to $10 \mu \mathrm{m}$, and emissivity of 0.98 . Readings were taken by keeping the IRT field of view at about $45^{\circ}$ with the canopy surface and $2 \mathrm{~m}$ of distance from the target (leaves). Ten to twelve Tc readings were used in the average Tc calculation, and the variation coefficients were maintained within 2 to $3 \%$ limits. 
The aerodynamic resistance $\left(\mathrm{r}_{\mathrm{a}}\right)$ was estimated through the equation presented by Allen et al. [11] and Jensen et al. [12]. Daily CWSI were obtained for morning and afternoon periods with the following equation ( [13] and [1]):

$$
\operatorname{CWSI}=\frac{\gamma \cdot\left(1+\frac{\left.\mathrm{r}_{\mathrm{c}} / \mathrm{r}_{\mathrm{a}}\right)-\gamma^{*}}{\Delta+\gamma \cdot\left(1+\mathrm{r}_{\mathrm{c}} / \mathrm{r}_{\mathrm{a}}\right)}\right.}{\Delta{ }^{2}}
$$

in which the symbol $\Delta$ represents the slope of the saturated vapor pressure-temperature relation $\left(\mathrm{Pa} /{ }^{\circ} \mathrm{C}\right)$, and was estimated according to Jackson et al. [14] mathematical model. The term $\gamma$ (in units of $\mathrm{Pa} /{ }^{\circ} \mathrm{C}$ ) is the psychrometric constant and was obtained as described in Brunt's procedure, according to Smith et al. [15]. The ratio $r_{\mathrm{c}} / \mathrm{r}_{\mathrm{a}}$ was determined according to Jackson [1], in terms of $R_{n}$, (Tc-Ta), vapor pressure deficit (VPD), and $r_{a}$. Afterwards, the $r_{c}$ values were obtained from (Tc-Ta) and $r_{a}$ daily values.

The crop situation in the maximum evapotranspiration condition $\left(\mathrm{ET}_{\mathrm{m}}\right)$ was provided by Treatment 2 , as well as the canopy resistance at $\mathrm{ET}_{\mathrm{m}}\left(\mathrm{r}_{\mathrm{cp}}\right)$ and the modified psychrometric constant $\left(\gamma^{*}\right.$ in units of $\left.\mathrm{Pa} /{ }^{\circ} \mathrm{C}\right)$, according to the formula

$$
y^{*}=y\left(1+r_{c p} / r_{a}\right)
$$

\section{Results and discussion}

All treatments received a total of $118.8 \mathrm{~mm}$ of applied water from seedling to 28 days after seedling (DAS), with 4-day average irrigation interval. Just after the 28 DAS, treatment differentiation started, with the application of pre-determined depths of water, according to the irrigation intervals. From seedling to harvest, the total amounts of applied water, including $66 \mathrm{~mm}$ of rainfall, were 482.0, 439.6, 385.6, 326.5, and $290.4 \mathrm{~mm}$ for T2, T4, T8, T12 and T16 treatments, respectively.

The crop water stress index results considered for analysis were from the growth period between the 29 and 80 DAS. Table 1 lists the crop yield and other yield components parameters. It was not observed statistical significance among the treatments for the number of pods per plant. The same behavior was observed for harvest index $(\mathrm{HI})$ and grain yield, with no response for irrigation frequencies of 2,4 , and 8 days. Also no responses were verified when comparing 8 and 12 days, and 12 and 16 days irrigation intervals. Satisfactory results were obtained for HI, grain yield, number of seeds per pod, and the weight of 1000 seeds in the treatment T8. Results show that irrigation frequency beyond 8-day intervals decreased the magnitude of the studied parameters, causing injury to the crop.

Table 1 also shows strong water stress levels for T12 and T16, resulting in reduction of grain yield and yield components parameters. Grain yield was the most affected one. 
Table 1. Number of pods per plant, number of seeds per pod, 1000-seed weigh, harvest index, and grain yield responses to different irrigation frequencies on beans (Phaseolus vulgaris L.)

\begin{tabular}{llllll}
\hline $\begin{array}{l}\text { Irrigation } \\
\text { frequency } \\
\text { (days) }\end{array}$ & $\begin{array}{l}\text { Pod Number } \\
\text { per plant }\end{array}$ & $\begin{array}{l}\text { Seed number } \\
\text { per pod }\end{array}$ & $\begin{array}{l}1000 \mathrm{seed} \\
\text { weight } \\
(\mathrm{g})\end{array}$ & $\begin{array}{l}\text { Harvest } \\
\text { index }\end{array}$ & $\begin{array}{l}\text { Grain yield } \\
\left(\mathrm{Kg}^{2} \mathrm{ha}^{-1}\right)\end{array}$ \\
2 & $11.4 \mathrm{a}$ & $4.8 \mathrm{a}$ & $239.6 \mathrm{ab}$ & $0.55 \mathrm{a}$ & $2755 \mathrm{a}$ \\
4 & $11.1 \mathrm{a}$ & $4.7 \mathrm{a} \mathrm{b}$ & $245.5 \mathrm{a}$ & $0.57 \mathrm{a}$ & $2750 \mathrm{a}$ \\
8 & $9.5 \mathrm{a}$ & $4.0 \mathrm{~b}$ & $241.6 \mathrm{ab}$ & $0.53 \mathrm{ab}$ & $2294 \mathrm{ab}$ \\
12 & $7.4 \mathrm{a}$ & $3.3 \mathrm{c}$ & $259.4 \mathrm{a}$ & $0.46 \mathrm{bc}$ & $1583 \mathrm{~b} \mathrm{c}$ \\
16 & $6.8 \mathrm{a}$ & $3.2 \mathrm{c}$ & $225.0 \mathrm{~b}$ & $0.42 \mathrm{c}$ & $1057 \mathrm{c}$ \\
Average & 9.2 & 4.0 & 242.2 & 0.51 & 2088 \\
VC & 25.16 & 7.33 & 3.73 & 5.65 & 15.44 \\
\hline
\end{tabular}

${ }^{1}$ Dry matter of the grain / Total dry matter (at the harvest)

2 Values expressed for $13 \%$ humidity

Means followed by the same letters do not present statistical significance by the Tukey test at 5 $\%$ probability level.

$\mathrm{VC}=$ Variation Coefficient

Assuming the grain yield of treatment $\mathrm{T} 2$ as the potential yield (no water stress condition), it was verified a reduction of $0.181,16.7,42.5$, and $61.6 \%$ in the grain weight caused water shortage in treatments $\mathrm{T} 4, \mathrm{~T} 8, \mathrm{~T} 12$, and $\mathrm{T} 16$, respectively.

Figures 1 and 2 show the crop water stress index variation with the crop growth period (expressed as days after seedling) at four irrigation frequencies (T4, T8, T12, and T16) and two measuring periods (morning and afternoon), respectively. Treatment T2 was assumed to have a crop with adequate water supply and maximum or potential evapotranspiration rate in the CWSI determination. The results show that T4 presented less oscillation in the CWSI values which were maintained close to the zero level. Therefore, four-day irrigation frequency did not cause water stress damage to the crop. This result can also be verified in the Table 1 where the crop yield and yield components behavior of $\mathrm{T} 2$ and $\mathrm{T} 4$ treatments are quite similar. By analyzing the two measuring periods (morning and afternoon), it can be noticed a similar tendency in the CWSI variation. But the highest CWSI values were obtained during afternoon readings. At first, this suggests that the best time for canopy temperature (Tc) reading is between 13:00 and 14:00 hours for CWSI studies.

The treatment that caused most water stress was T16, where the CWSI reached values of 0.26 and 0.40 for morning and afternoon periods, respectively. Table 1 results emphasize the damage caused to the crop.

Overall, the results show that a CWSI value of about 0.15 may be used as a limit for irrigation water management strategies to diferentiate the irrigated crop from a nonstressed to a stressed condition, in order to avoid signifficant yield loss.

This limit of 0.15 derives from the observation that $\mathrm{T} 4$ and $\mathrm{T} 8$ treatments presented maximum CWSI values of roughly 0.10 and 0.20 , respectively. At T4, results indicate that the crop was also adequately supplied with water (no-stress, similar to T2). On the other hand, at T8 the crop may have experienced a certain degree of water stress. These results agree with the results from Kobayashi [5] for the same crop. 


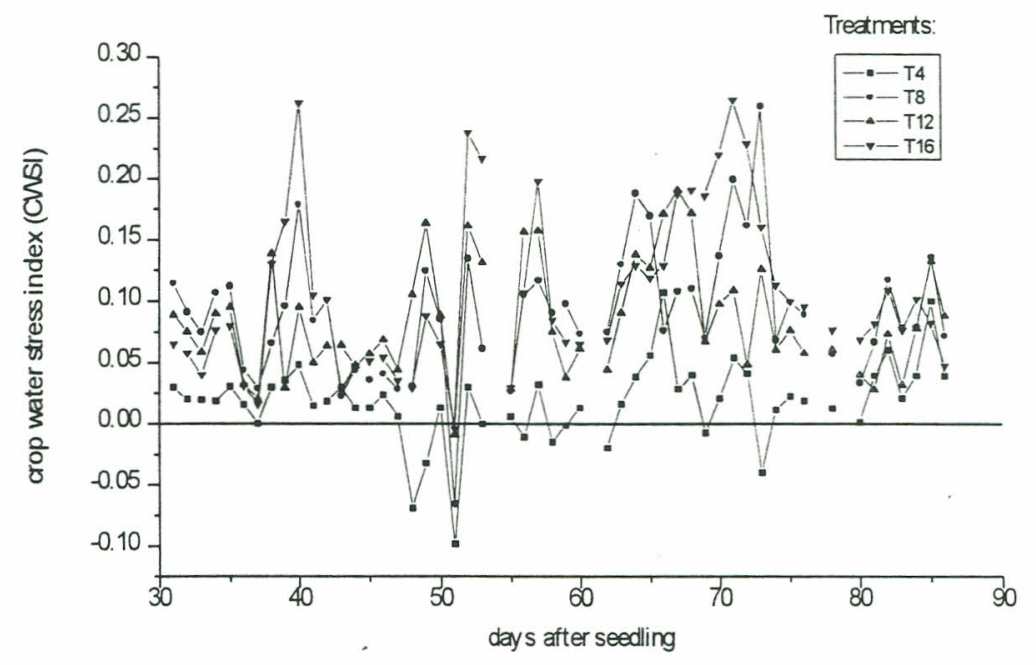

Fig. 1. Crop water stress index versus crop growth period (expressed as days after seedling) at four irrigation frequencies (T4, T8, T12, and T16) for measurements in the morning period (EMBRAPA, Sete Lagoas, MG, Brazil, 1995).

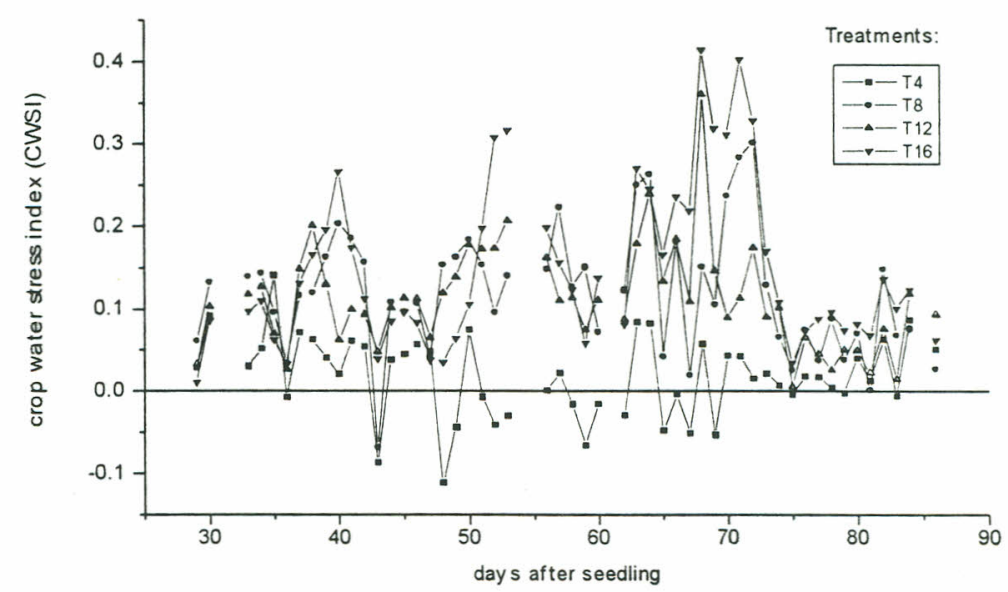

Fig. 2. Crop water stress index versus crop growth period (expressed as days after seedling) at four irrigation frequencies (T4, T8, T12, and T16) for measurements in the afternoon period (EMBRAPA, Sete Lagoas, MG, Brazil, 1995). 


\section{Conclusions}

The potential grain yield $\left(2,755 \mathrm{Kg} \cdot \mathrm{ha}^{-1}\right)$ was obtained with the irrigation frequency of two days, under no water stress. A reduction of $0.18,16.7,42.5$, and $61.6 \%$ was verified in the grain weight due to treatments $T 4, T 8, T 12$, and $T 16$, respectively (tretments with water shortage). There was no statistical significance for grain yield among the 2-, 4-, and 8-day irrigation intervals.

The total depth of applied water, including $66 \mathrm{~mm}$ of rainfall, were of 482.0, 439.6, $385.6,326.5$, and $290.4 \mathrm{~mm}$ for 2-, 4-, 8-, 12- and 16-day of irrigation frequency, respectively.

It was verified a similar tendency of the CWSI variation in the periods of measurement (morning and afternoon). The highest CWSI values were obtained during afternoon readings, suggesting that as the best period for canopy temperature (Tc) measurements. The highest water stress was obtained with 16-day irrigation frequency, when the CWSI reached values of 0.26 and 0.40 , for morning and afternoon periods, respectively.

A crop water stress index value of about 0.15 may be used as a limit for irrigation water management to differentiate the irrigated crop from a non-stressed to a stressed condition, as a criteria to avoid signifficant yield loss.

\section{References}

1. 1.Jackson, R.D. (1982) Canopy temperature and crop water stress. Advances in irrigation. New York, Vol.1, pp.43-85.

2. Folegatti, M.V. (1988) Avaliação do desempenho de um "scheduler" na detecção do estresse hídrico em cultura do feijoeiro (Phaseolus vulgaris L.) irrigada com diferentes lâminas. Piracicaba: ESALQ, 1988. 188p. Thesis (Doctor in Agronomy) - Escola Superior de Agricultura "Luiz de Queiroz", Universidade de São Paulo, Brazil.

3. Clawson, K.L., Jackson, R.D. and Pinter Jr., P.J. (1989) Evaluating plant water stress with canopy temperature differences. Agronomy Journal. Vol.81, pp.85863.

4. Pitts, D.J., Wright, R.E., Kimbrough, J.A. and Johnson, D.R. (1990) Furrow irrigated cotton on clayed soil in the Lower Mississipi River Valley. Applied Engineering in Agriculture, Vol.6, pp.446-52.

5. Kobayashi, M.K. (1996) Determinação do índice de estresse hídrico da cultura do feijoeiro (Phaseolus vulgaris L.) por meio da termometria a infravermelho, e do fator de disponibilidade de água no solo, em minilisímetro de pesagem. Viçosa: UFV, 1996. 90p. Thesis (M.Sc. in Agricultural Engineering) - Universidade Federal de Viçosa, Brazil.

6. Inoue, Y. (1991) Remote and visualized sensing of physiological depression in crop plants with infrared thermal imagery. Japan Agricultural Research Quarterly, Vol.25, pp.1-5.

7. Idso, S.B., Jackson, R.D., Pinter Jr., P.J., Reginato, R.G. and Hatfield, J.L. (1981) Normalizing the stress-degree-day parameter for environmental variability. Agricultural Meteorology, Vol.24, pp.45-55. 
8. Andrews, P.K., Chalmers, D.J. and Moremong, M. (1992) Canopy-air temperature differences and soil water as predictors of water stress of apple trees grown in a humid, temperate climate. Journal American Society Horticultural Science, Vol.117, pp.453-8.

9. Grimes, D.W., Wiley, P.L. and Sheesley, W.R. (1992) Alfalfa yield and plant water relations with variable irrigation. Crop Science., Vol.32, pp.1381-7.

10. Silva, B.B. (1994) Estresse hídrico em algodoeiro herbáceo irrigado evidenciado pela termometria infravermelha. Campina Grande: UFPB, 1994. 139p. Thesis (Doctor in Civil Engineering) - Centro de Ciências e Tecnologia, Universidade Federal da Paraíba, Brazil.

11. Allen, R.G., Jensen, M.E., Wright, J.L. and Burman, R.D. (1989) Operational estimates of reference evapotranspiration. Agronomy Journal, Vol.81, pp.650-62.

12. Jensen, M.E., Burman, R.D. and Allen, R.G. (1990) Evapotranspiration and irrigation water requirements. New York: ASCE, 332p.

13. Jackson, R.D., Idso, S.B., Reginato, R.J. and Pinter Jr., P.J. (1981) Canopy temperature as a crop water stress indicator. Water Resource Research, Vol.17, pp. 1133-8.

14. Jackson, R.D., Kustas, W.P. and Choudhury, B.J. (1988) A reexamination of the crop water stress index. Irrigation Science, Vol.9, pp.309-17.

15. Smith, M., Segeren, A., Pereira, L.S., Perrier, A. and Allen, R. (1991) Report on the expert consultation on procedures for revision of FAO guidelines for prediction of crop water requirements. Rome: FAO, 45p. 